\title{
Phytoprotection
}

\section{Tissue invasion and alteration in eggplant infected with Verticillium dahliae: A light and transmission electron microscopy study}

\section{Observations en microscopie photonique et électronique à transmission du mode d'infection et d'altération des tissus chez l'aubergine infectée par le Verticillium dahliae}

\author{
Guillemond B. Ouellette et Hélène Chamberland
}

Volume 87, numéro 1, avril 2006

URI : https://id.erudit.org/iderudit/013968ar

DOI : https://doi.org/10.7202/013968ar

Aller au sommaire du numéro

Éditeur(s)

Société de protection des plantes du Québec

ISSN

0031-9511 (imprimé)

1710-1603 (numérique)

Découvrir la revue

Citer cet article

Ouellette, G. B. \& Chamberland, H. (2006). Tissue invasion and alteration in eggplant infected with Verticillium dahliae: A light and transmission electron microscopy study. Phytoprotection, 87(1), 29-42.

https://doi.org/10.7202/013968ar
Résumé de l'article

Un objectif de cette étude a été de caractériser, dans des plants inoculés, les composantes exogènes aux éléments de vaisseaux, dont les enduits sur la paroi vasculaire, et leurs liens avec des altérations cellulaires et la présence de matière opaque dans les lamelles mitoyennes et le périplasme de cellules paratrachéales. Des tests pour localiser certains composés pariétaux ont été utilisés. Les enduits étaient formés de diverses couches, dont une première, mince et opaque et d'aspect membranaire, et d'autres plus épaisses et translucides alternant avec des couches opaques. Plusieurs gonflements circulaires se trouvaient dans ou à la marge de ces strates (VWLM). D'autres réseaux sinueux, apparemment issus de l'espacement des bandes formant la première couche de l'enduit, se trouvaient dans les vaisseaux. La matière périplasmique contenait des structures filamenteuses et de nombreuses particules opaques d'allure ribosomique. La partie interne des champs de ponctuations montrait des bandes opaques éparses, non marquées pour la cellulose, recouverte d'une couche plus compacte, marquée pour ce substrat. Les résidus altérés n'étaient libérés dans les vaisseaux qu'en cas de rupture du VWLM montrant l'absence de marquage pour ces deux substrats. Les épaississements secondaires des parois vasculaires étaient souvent altérés ou détachés de leur base, expliquant la présence de matière translucide marquée pour la cellulose dans les vaisseaux. 


\title{
Tissue invasion and alteration in eggplant infected with Verticillium dahliae: A light and transmission electron microscopy study
}

\author{
Guillemond B. Ouellette ${ }^{1}$ and Hélène Chamberland ${ }^{2}$
}

Received 2005-10-31; accepted 2006-05-01

PHYTOPROTECTION $87:$ 29-42

Light and transmission electron microscopy observations of Verticillium-inoculated eggplants are reported. Results of tests for cellulose and chitin are also presented. Opaque, vessel wall lining matter (VWLM) generally occurred, connected to elements identified as fungal cells, and extending into vessel secondary walls and across pits. VWLM was also confluent with similar matter extensively pervading middle lamellae and causing their alterations. The thickest VWLM was stratified as alternating opaque and more lucent bands, with the opaque ones being similar to the first layer deposited. Many loops were included in or bulged from the VWLM layers. Lace-like structures also occurred in vessel lumina as apparent distensions of the basic, first opaque layer of this VWLM. Large amounts of similar opaque matter occurred in the periphery of paratracheal cells with altered content. This matter contained filamentous-like structures and frequently opaque particles reminiscent of ribosomes. The pitted areas were much altered as an internal shred-like network, unlabelled for cellulose, covered by an outer opaque and compact cellulose-labelled layer, itself overlaid by an unlabelled VWLM. Release of labelled material from these altered areas only occurred at locations of VWLM ruptures. Detachment and alterations of the adjacent vessel wall secondary thickenings were noticeable and accounted for the presence of lucent cellulose-labelled matter in vessel lumina.

Keywords: Cell wall alterations, labelling for cellulose and chitin, opaque matter, periplasmic areas, verticillium wilt, vessel wall coating, vessel wall lining material.

[Observations en microscopie photonique et électronique à transmission du mode d'infection et d'altération des tissus chez l'aubergine infectée par le Verticillium dahliae]

Un objectif de cette étude a été de caractériser, dans des plants inoculés, les composantes exogènes aux éléments de vaisseaux, dont les enduits sur la paroi vasculaire, et leurs liens avec des altérations cellulaires et la présence de matière opaque dans les lamelles mitoyennes et le périplasme de cellules paratrachéales. Des tests pour localiser certains composés pariétaux ont été utilisés. Les enduits étaient formés de diverses couches, dont une première, mince et opaque et d'aspect membranaire, et d'autres plus épaisses et translucides alternant avec des couches opaques. Plusieurs gonflements circulaires se trouvaient dans ou à la marge de ces strates (VWLM). D'autres réseaux sinueux, apparemment issus de l'espacement des bandes formant la première couche de l'enduit, se trouvaient dans les vaisseaux. La matière périplasmique contenait des structures filamenteuses et de nombreuses particules opaques d'allure ribosomique. La partie interne des champs de ponctuations montrait des bandes opaques éparses, non marquées pour la cellulose, recouverte d'une couche plus compacte, marquée pour ce substrat. Les résidus altérés n'étaient libérés dans les vaisseaux qu'en cas de rupture du VWLM montrant I'absence de marquage pour ces deux substrats. Les épaississements secondaires des parois vasculaires étaient souvent altérés ou détachés de leur base, expliquant la présence de matière translucide marquée pour la cellulose dans les vaisseaux.

Mots clés : Bris parois cellulaires, enduits sur la paroi vasculaire, espaces périplasmiques, marquage pour cellulose et chitine, matière opaque, recouvrement des parois vasculaires, verticilliose.

1. Natural Resources Canada, Canadian Forest Service, Laurentian Forestry Centre, 1055 du P.E.P.S., P.O. Box 10380, Stn. SainteFoy, Québec (Quebec), Canada G1V 4C7; corresponding author e-mail: gouellette@cfl.forestry.ca

2. Formerly, Pavillon C.E. Marchand, Université Laval, Québec (Quebec), Canada G1K 7P4 


\section{INTRODUCTION}

In the "Proceedings of the Seventh International Symposium on Verticillium" (Tjamos et al. 1998), the part on host-parasite interactions is introduced as: "Past achievements and future molecular prospects" (Cooper 1998). In the second introductory sentence, the author mentions that "there is little to add from the last decade or so" that had not been previously summarized, stressing that progress on fungal wilt pathogens has lagged behind with regard to other fungal plant pathogens, despite the fact that diseases caused by these fungi, including Verticillium, are some of the most destructive worldwide (see also Pegg and Brady 2002). The verticillium wilt of eggplant is ranked as one of these diseases (Cirulli et al. 1998). In fact, most eggplant cultivars are moderately to highly susceptible, and commercial, truly resistant cultivars, had apparently not yet been developed in 1998 (Cirulli et al. 1998). Grafts of eggplant scions to possibly resistant root stock appeared promising but some reports indicate that this combination may eventually lead to a condition of susceptibility for both partners (Garibaldi et al. 2005).

In considering the other titles listed in Tjamos et al. (1998), one realizes that most are oriented towards genetic aspects or physiological factors of pathogenesis that could lead to a better disease comprehension and eventual production of resistant plants (for example see Cirulli et al. 1998; Cooper et al. 1998; McFadden 1998; Tomescu et al. 1998). It is surprising that in all these accounts, there are no reports of histological or ultrastructural studies of these diseases, as if it could be taken for granted that the questions about the origin and nature of extrinsic matter occurring in vessel lumina, and about visible host cell alterations and reactions, the various growth forms of the pathogens, and so on, were exhausted and that nothing new could be learned on these subjects. There is also a sustained impression that all the causalities of these types of diseases are restricted to events occurring in vessels (Pegg and Brady 2002). Cooper (1998) nevertheless has tagged some of these aspects with question marks, including the question of vessel coatings as a mechanism of resistance (e.g. Robb et al. 1987, 1989). As hyphal cells are often surrounded by matter similar to coating, in verticillium and other wilt diseases, this was considered as supportive evidence for the notion of coating formation corresponding to an acquired resistance. This view, however, has not been generally agreed upon, and the following statement by Pegg and Brady (2002, p. 172) is pertinent: "While it is attractive to interpret hyphal coating as a defence response, it is not a ubiquitous feature of infection in resistant plants and is commonly seen in pathogenic susceptible reactions." Other works on this aspect are referred to in the Discussion section.

We have already described particular modes of pathogen development, of tissue alterations, of host cell reactions and related aspects concerning Dutch elm disease and Fusarium wilts of carnation, tomato and staghorn sumac (Charest et al. 2004; Ouellette 1978b; Ouellette et al. 1995, 1999, 2004a, 2004b, 2004c, 2004d, 2004e, 2005a, 2005b). These works present peculiar characteristics of pathogen structures, of host cell wall and content alterations related to extensive tissue invasion by opaque matter, not ascribable to a host origin, of various host cell reactions and so on, and more than circumstantial evidence was presented to show that most of the material lining vessel walls did not always correspond to the notions of coating as supported by others. For this reason, we will not use herein the term coating (contrary to our previous usage of this term) to designate this vessel wall lining matter (VWLM).

The present work on Verticillium-infected eggplants is an expansion of earlier brief mentions (Ouellette and Chamberland 1993, Ouellette et al. 2004e) that concentrate on aspects of tissue invasion and of host cell alterations in relation to matter lining vessel walls and of its links with pathogen cells and the interrelated abundant opaque matter occurring intercellularly and across host cell walls.

\section{MATERIALS AND METHODS}

\section{Isolates and inoculum}

Three isolates of Verticillium dahliae Kleb. (as indicated on a few notes from the late Dr. Gilles Pelletier) were used for this study. One of his isolates (\# 10) was obtained from strawberry in Guelph (Ontario), in 1969; a second one (\# 1758) was obtained from eggplant, also in 1969 in Guelph; a third one (\# 1702) was obtained (by Dr. Claude Aubé and Mr. Alain Delvaux) from potato in Sainte-Clothide (Quebec), in 1963. These isolates were grown on potato dextrose agar for 4 to $6 \mathrm{~d}$ and surface washings of conidia with sterile $\mathrm{H}_{2} \mathrm{O}$ were used as inoculum (adjusted to approximately $1 \times 10^{6} \mathrm{~mL}^{-1}$ conidia).

\section{Plant samples}

Eggplants (Solanum melongena L., probably cultivar Black Beauty) susceptible to Verticillium infection were grown from seeds in $20 \mathrm{~cm}$ pots in a sterilized peat moss soil mixture in a light- and temperaturecontrolled chamber (Faculté des sciences de l'agriculture et de I'alimentation, Université Laval, Québec). Plants were regularly watered but not fertilized during the experiment period. They were inoculated at their five or six leaf stage in late spring by making an incision with a sterilized blade across a drop of inoculum placed at the base of the stem, which was previously wiped with $70 \%$ ethanol. Sets of four plants were inoculated with either of the isolates, and two noninoculated plants were used as controls. The experiment was conducted in 1972.

Samples (approximately $2 \mathrm{~mm} \times 2 \mathrm{~mm}$ ) were taken at 1, 4, 7 (or 8) and 14 (or 15) d after inoculation. On the first sampling date, specimens were taken at the base of the stem ( $5 \mathrm{~cm}$ above the inoculation wound) and on the other sampling dates, they were taken at the base and at or slightly above the front of visible invasion which was either in mid-stem or upper stem portions and from petioles a few $\mathrm{mm}$ from the stem. This was to observe the various stages and degrees of tissue colonization. Only samples from which the pathogen could be re-isolated were selected for examination. 
Ten to fifteen blocks from each sampling site were fixed as described in Ouellette (1978a) with $4 \%$ glutaraldehyde in cacodylate buffer for $2 \mathrm{~h}$ in vials kept in melting ice and then at $4^{\circ} \mathrm{C}$, followed by postfixation with $1 \%$ osmium tetroxide in the same buffer for $2 \mathrm{~h}$ at room temperature. Dehydration with ethanol and embedding with Epon were carried out according to standard procedures.

\section{Light (LM) and transmission electron microscopy (TEM) observations}

Semi-thin sections obtained with a glass knife and stained with safranin and toluidine blue (Ouellette 1978a) were used for observations with an Ortholux Plan microscope. For electron microscopy, thin (gold) sections obtained with a diamond knife were mounted on Formvar coated copper grids, or nickel grids for cytochemical tests, and stained with uranyl acetate and lead citrate. Examinations were made with a Philips 200 or 300 microscope at $80 \mathrm{kV}$. Ordinarily, two sections (and three more when cytochemical tests were conducted) were examined in TEM and several more in LM.

\section{Cytochemical tests}

Tests to detect cellulose and chitin were carried out in 1992 using the 1972 embedded samples and using colloidal gold-complexed probes as described in Ouellette et al. (1995). Briefly, in tests for $\beta-1,4-$ glucans, ultrathin sections were first floated on a drop of phosphate buffer saline (PBS) containing $0.02 \%$ polyethylene glycol (PEG) 20000 (pH 6.5) for 5 min, then for $30 \mathrm{~min}$ on a drop of a gold-complexed exoglucanase (EC 3.2.1.91), rinsed with PBS and distilled water, and stained as mentioned above. Controls included the addition of $\beta$-D-glucans (from barley) to the enzyme-gold-complex or omitting the enzyme before treating the sections. In tests for chitin, sections were incubated on a drop of wheat germ agglutinin (WGA) (50 $\mathrm{g} \mathrm{m} \mathrm{mL}^{-1}$ in PBS) for 30-60 min, rinsed with PBS, and then placed on a drop of ovomucoidgold complex for $30 \mathrm{~min}$, and rinsed as above. Controls included: 1) incubation of the sections with the lectin adsorbed with $N, N^{\prime}, N^{\prime \prime}$-triacetylchitotriose and then with the ovomucoid complex; 2 ) incubation of sections with WGA, then unlabelled ovomucoid, followed by the ovomucoid-gold complex; and 3) incubation with the ovomucoid-gold complex, with the lectin incubation step being omitted.

\section{RESULTS}

Observations are from inoculations made with either isolate \# 1758 or isolate \# 10, which caused somewhat similar tissue disorders. Isolate \# 1702 caused no appreciable tissue damage and results with this isolate are not reported.

\section{LM observations}

In control samples of young (Fig. 1a) or older tissue, and in non-invaded portions of diseased samples, vessel elements were free of extraneous content and their walls were intact. Vessel elements adjoined axial parenchyma cells of various lengths which, in metaxylem tissue, lacked secondary walls. Some long fusiform cells corresponding to fibres also adjoined vessel elements (e.g. Fig. 1b).

As shown in Fig. 1b-i, the greatest tissue damage occurred in metaxylem or early secondary xylem, mostly in samples of mid-stem portions or petioles, at some distance from the inoculation point. Comparatively, vessel elements in the secondary xylem were relatively intact, except for the occurrence of material accumulating on vessel walls and of a few visible pathogen cells.

A characteristic of invaded vessel elements in all infected regions was the occurrence of thin layers of vessel wall lining matter (VWLM), also found on pit membranes (Fig. 1b-h). At the tips of advancing streaks, this VWLM was discontinuous at sites or imperceptible. In these seemingly recently invaded vessel elements, the VWLM was confluent with larger strongly stained bodies that probably represented fungal cells (Fig. 1e). In the proximity of invaded vessel elements, others appeared to be free of extrinsic matter (Fig. 1c).

Opaque matter, as masses or small bands, frequently occurred intercellularly next to invaded vessel elements (Fig. 1b, d, f-i). This matter was connected to the VWLM, extending from along pit membranes or across these and through middle lamellae of adjacent cells (Fig. 1f-h). These host walls were often eroded or disrupted (Fig. 1d) in association with this matter and/or with fungal elements having grown through the membranes (Fig. 1f, g). Cell separation in regions apparently more remote from vessel elements, particularly of ray cells, was also noticeable (Fig. 1b).

\section{TEM observations}

Pit membrane and primary wall alterations. Pronounced dislocation of middle lamellae between vessel elements and paratracheal cells, related to opaque matter, is shown in Fig. 2a, as counterparts of LM observations. Strongly swollen pit membranes and/or middle lamellae occurred in the metaxylem, bordering altered and often detached secondary wall thickenings. The presence of cellulose-labelled material in vessel lumina seemingly resulted from these alterations (Fig. 2c). The altered pit fields and confluent wall were characterized by shred-like distended parts unlabelled for cellulose and by outer more compact parts strongly labelled for this substrate (Fig. 2c). These pronounced alterations nevertheless remained confined by the unlabelled VWLM layer, unless it was ruptured, in which case release of labelled components into vessel lumina appeared to have occurred (Fig. 2c).

VWLM. The thinnest layer on vessel walls, in all vessel types, appeared as a thin opaque band which frequently spanned from one vessel element to another across pit membranes (Fig. 3a) or extensions from it reached some distance into the vessel secondary walls (Fig. 3b). The VWLM did not label for chitin but the vessel secondary walls did (Fig. 3b), as they also did for cellulose (see below).

In seemingly more advanced infection, the VWLM layers were generally thick and stratified, increasing 


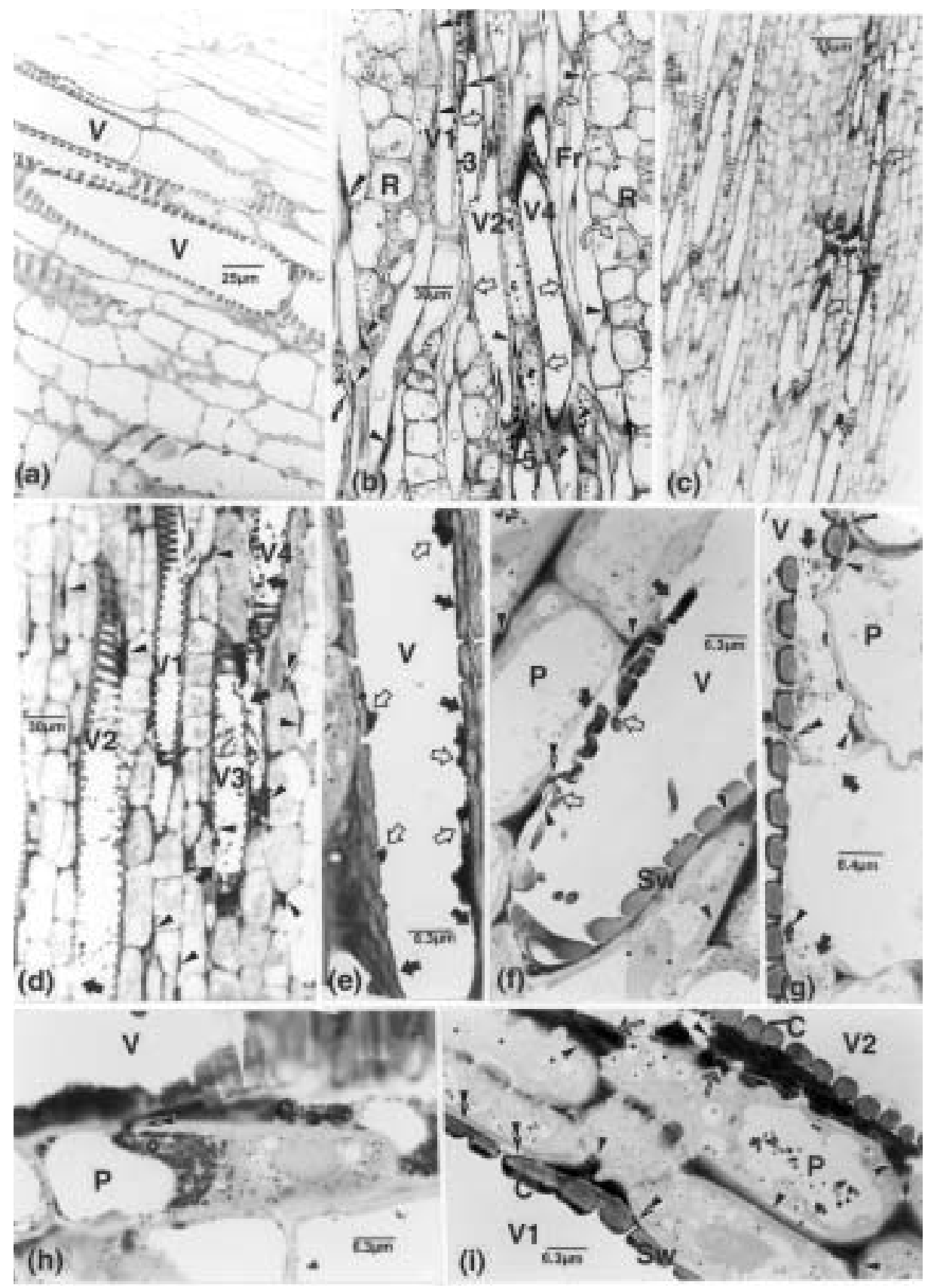

Figure 1. LM observations. (a): control sample. Metaxylem vessel lumina are free of content. (b-h): samples from the base, mid- and upper stem portions or petioles, 1 to $15 \mathrm{~d}$ after inoculation. (b): VWLM is mostly continuous (light arrows) on straight wall portions of V2-V5, or contours pit borders and chambers. Intercellular or intramural bands or masses of OM (opaque matter) (arrowheads) adjoin many cells. VWLM is connected to this OM (superimposed arrowheads). Some ray cell middle lamellae are dislocated (curved arrows). (c): altered tissues (dark arrow) border vessel elements with VWLM (light arrows), which is seemingly lacking in most vessel elements located elsewhere. (d): some of the secondary thickenings appear to have been dislodged (arrows, V2-V4, and some of the following figures), in association with fungal elements. Many intercellular masses of OM (arrowheads) are distinguishable. (e): from a sample taken at the tip of advancing streaks. Bodies probably representing fungal cells (light arrows) in places are confluent with VWLM (dark arrows). (f): some intercellular OM masses (arrowheads) and fine filamentous structures (light arrows), one connected to a fungal cell (upper light arrow), are confluent with the VWLM (superimposed arrowheads) and associated with alteration of secondary thickenings (dark arrows). (g): the OM (arrowheads), some confluent with the VWLM or extending across altered pit membranes (superimposed arrowheads), is associated with parenchyma cell wall ruptures (arrows) and detachment from the vessel wall. (h): an intercellular band of OM (superimposed arrowheads) present across a parenchyma cell wall. (i): VWLM (C) is thick in V1 but thin and localized in V2. OM masses are present intramurally or intercellularly (arrowheads), confluent with the VWLM (superimposed arrowheads), or in the cell periplasm obscuring their walls (arrows), next to still intact cytoplasm. C, vessel wall lining material (VWLM); Fr, fibre; P, parenchyma cell; R, ray cell; Sw, vessel secondary wall; V, vessel element. 

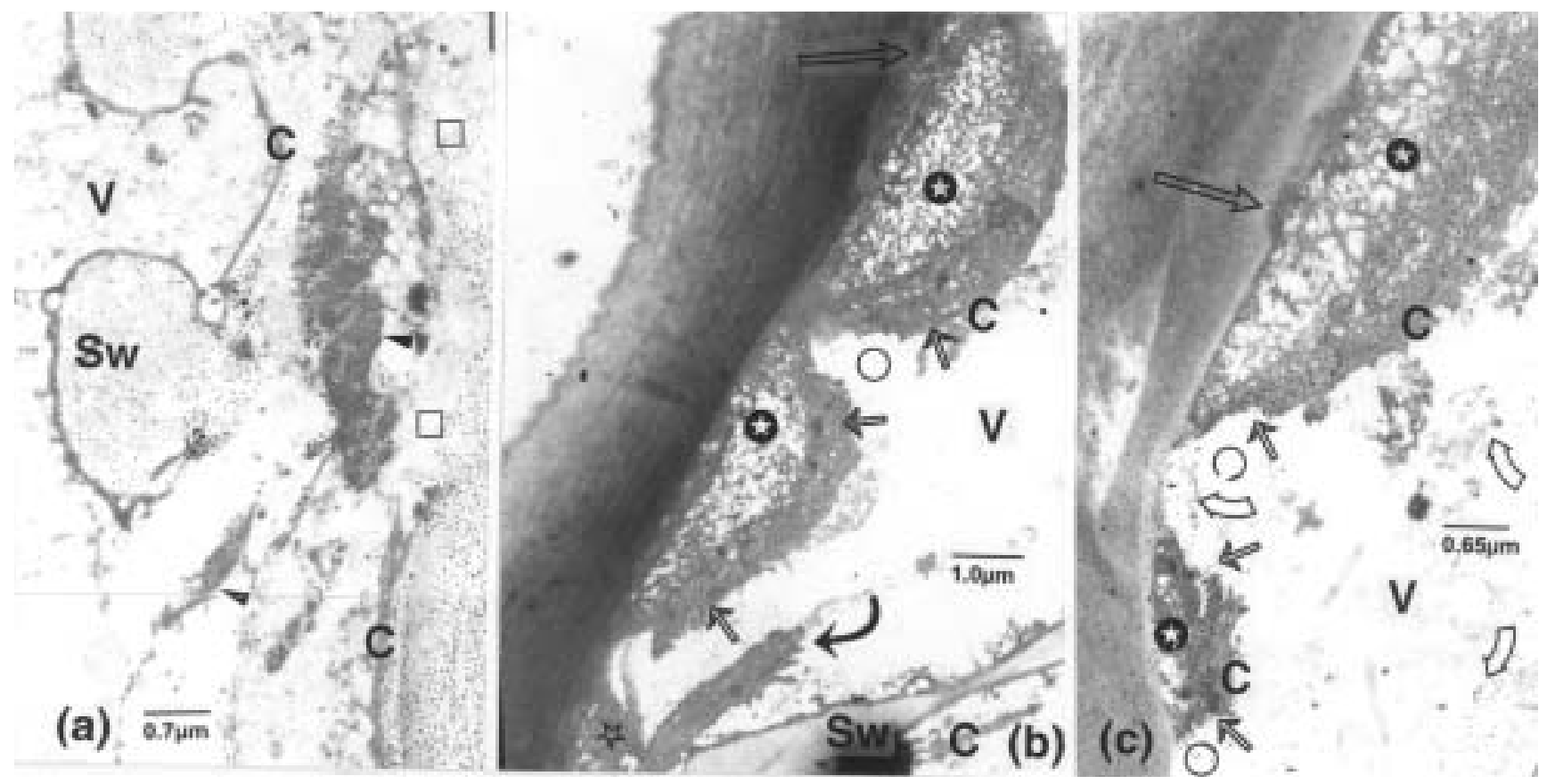

Figure 2. TEM observations, metaxylem tissue. (a): labelling for cellulose. Dislocation of thickenings and ruptures of VWLM are associated with masses of OM (arrowheads). Regions of the subtending host wall (squares) are altered in relation to vesicular-like bodies. (b): internal portions of pitted areas (stars) are dislocated shred-like and their outer parts are more compact. The underlying wall is also altered (long, light arrow). Ruptures in the VWLM (short, light arrows) are visible. The curved arrow points to an eroded wall portion. (c): a counterpart of $\mathbf{b}$, labelled for cellulose, the short, thin arrows and the long, light arrow pointing to similar areas. Whereas the more compact portions of the pitted areas are labelled, the shredded portions (stars) and the VWLM are unlabelled. The curved, light arrows indicate concentrations of gold particles associated with altered portions of Sw. C = VWLM; Sw, vessel secondary thickening; $V$, vessel.

in thickness apparently by adding alternating layers of differing opacities (the first, opaque, apposed to the vessel wall denoted hereafter as outer one and the others as inner ones). The opaque ones were generally the thinnest (Fig. 3c, d), but in some cases the innermost opaque one was thicker (Fig. 3d, e). It was noteworthy that this innermost opaque layer bridged and/or closely contoured fungal cells. The VWLM was occasionally covered by remnants of host cell content, recognizable by the presence of starch grains amongst other components that could have slipped into vessel lumina following wall ruptures (see Fig. 1g). The VWLM layers also contained many loops which were devoid of content or circumscribed material connecting with one of the layers (Fig. 3c, e, f). In some situations, a thin compact layer extended long distances along vessel walls.

The larger fungal cells were usually delimited by equally stratified layers similar to those of the VWLM, with layers of similar opacity being contiguous (Fig. 3e, f). However, at these points of contact or close to them, some of the layers were missing.

In some instances, instead of layers similar to those just described, vessel walls were lined by paired bands (Fig. 4a). This illustration shows that whereas one of the bands was closely apposed to the vessel wall, the other, outer one was separated from it at varying distances, meandering into the vessel lumen and producing a lacy appearance. The outer band showed types of outgrowths sometimes having the appearance of spherical bodies. This band also appeared thicker and more opaque at these points of extension or when they contacted other bands. Some masses of dense matter were associated with both bands. Another feature of VWLM was its being occasionally covered by paired, unequally spaced bands, as shown above, that were ornamented with opaque particles (Fig. 4b). Many similar particles also occurred in fine matter that appeared to be associated or interconnected with these bands.

Large masses of opaque matter also extended appreciable distances along vessel walls and around vessel rims, confluent with a VWLM-like layer (Fig. $5 a)$. On the vessel lumen side, these masses, in which occurred many opaque particles intermixed with other nearly homogeneous components, were confined by a distinct band (Fig. 5a, b). Some of the particles were associated with distinct strands, as in the case illustrated in Fig. 4b. Similar, often large, convergent masses of opaque material on vessel walls were associated with inward displacements of the native and inner protective-like layers of adjoining paratracheal parenchyma cells (Fig. 5c-g). These masses likewise mostly contained small opaque bodies, masses or stretches of homogeneous, fine material, and/or larger compact bodies (Fig. 5e, g; those illustrated by thin, light arrows in these figures 


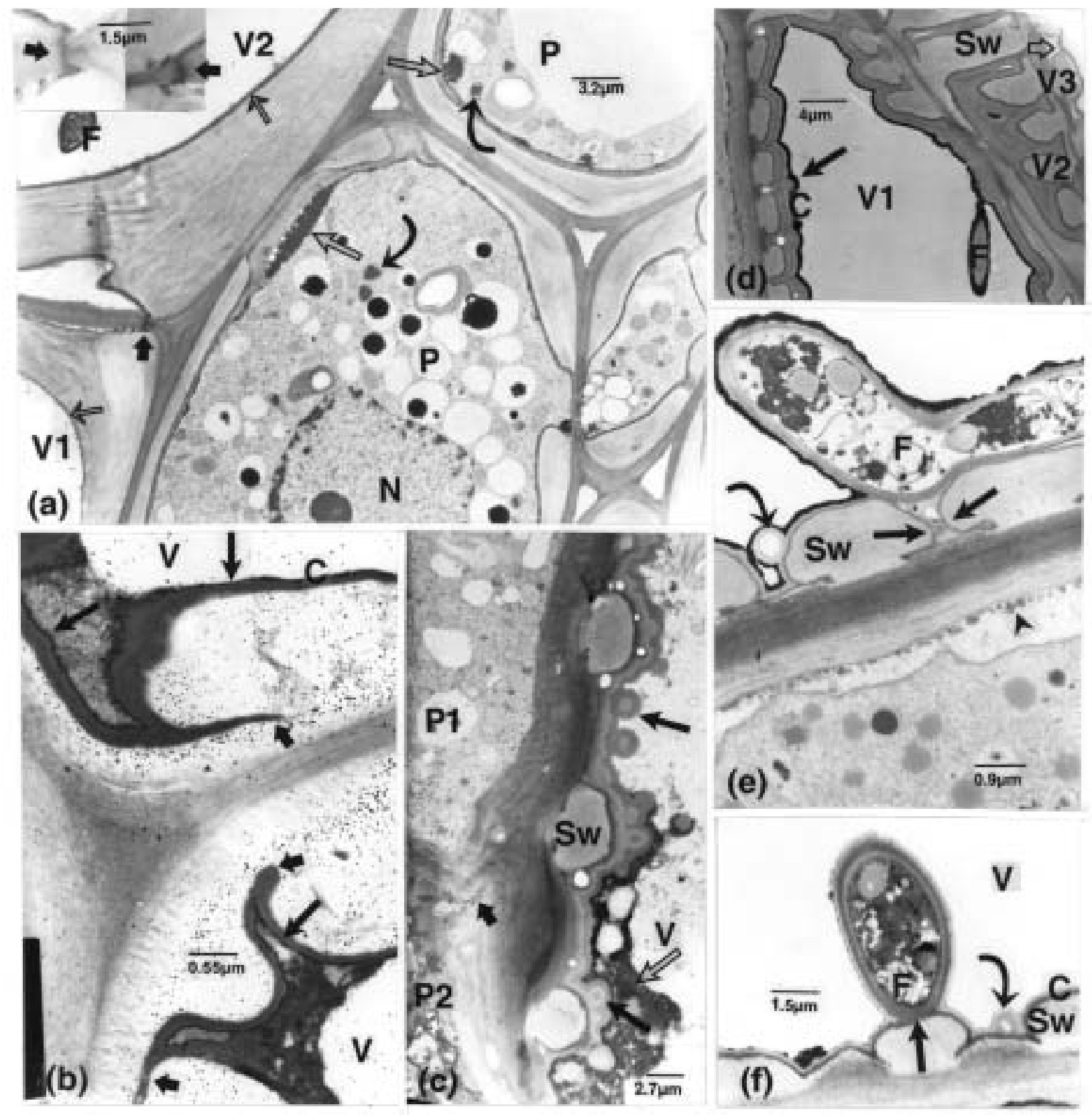

Figure 3. TEM observations. As for figure 1, samples are from various host plant portions taken at different intervals after inoculation. (a): from secondary xylem. The VWLM (thin, light arrows), visible as only a thin band in V1, is overlaid by a less opaque layer in V2; it is present across the intertracheary pit membrane (dark arrows), whose extremities are shown enlarged in the insets. A new wall layer sealing off pits in one cell is present in the paratracheal cells. Some of the paramural opaque material (thick, light arrows) (seen to be amorphous at higher magnifications) is apparently connected to a vacuole (upper cell). Several peroxisomes (curved arrows) occur in the cells. (b): the VWLM extends into the vessel secondary wall (short, dark arrows). The inner VWLM layer (long arrows) is exceptionally more opaque than its outer part. The chitin probe has bound to this vessel wall but not to the VWLM. (c): VWLM with alternating layers of varying opacity and with loops or humps in the innermost layers (long, dark arrows). The VWLM from the vessel wall inwards displays the following layers: opaque, more lucent, and moderately opaque. A mass of dense matter (light arrow) also covers the VWLM at places. Remnants of host cytoplasm also occur (see top part) in the vessel lumen. Walls and content of cell P2 are strongly altered (short, dark arrow). (d): the VWLM in V1 is stratified as in c, but the innermost, opaque layer (dark arrow) is exceptionally thicker than the outermost one; a similar layer reaches to and surrounds the fungal cell. The vessel V2 with similar VWLM filling its lumen was seemingly obliquely sectioned. The light arrow in V3 points to a thin VWLM. $(\mathbf{e}, \mathbf{f})$ : relation of pathogen cells with the VWLM, bulging into loops at sites (curved arrows). (e): some of the VWLM layers are lacking, appearing only as a single layer around pit borders (arrows) and the thickening underlying the fungal cell. (f): the fungal cell wall is apparently three-layered, the more lucent one being confluent with the lucent innermost layer of the VWLM, and the inner, opaque one adjoining the VWLM opaque layer (arrow). C = VWLM; F, fungal cell; $N$, nucleus; $P$, parenchyma cell; Sw, vessel secondary thickening; $V$, vessel element. 

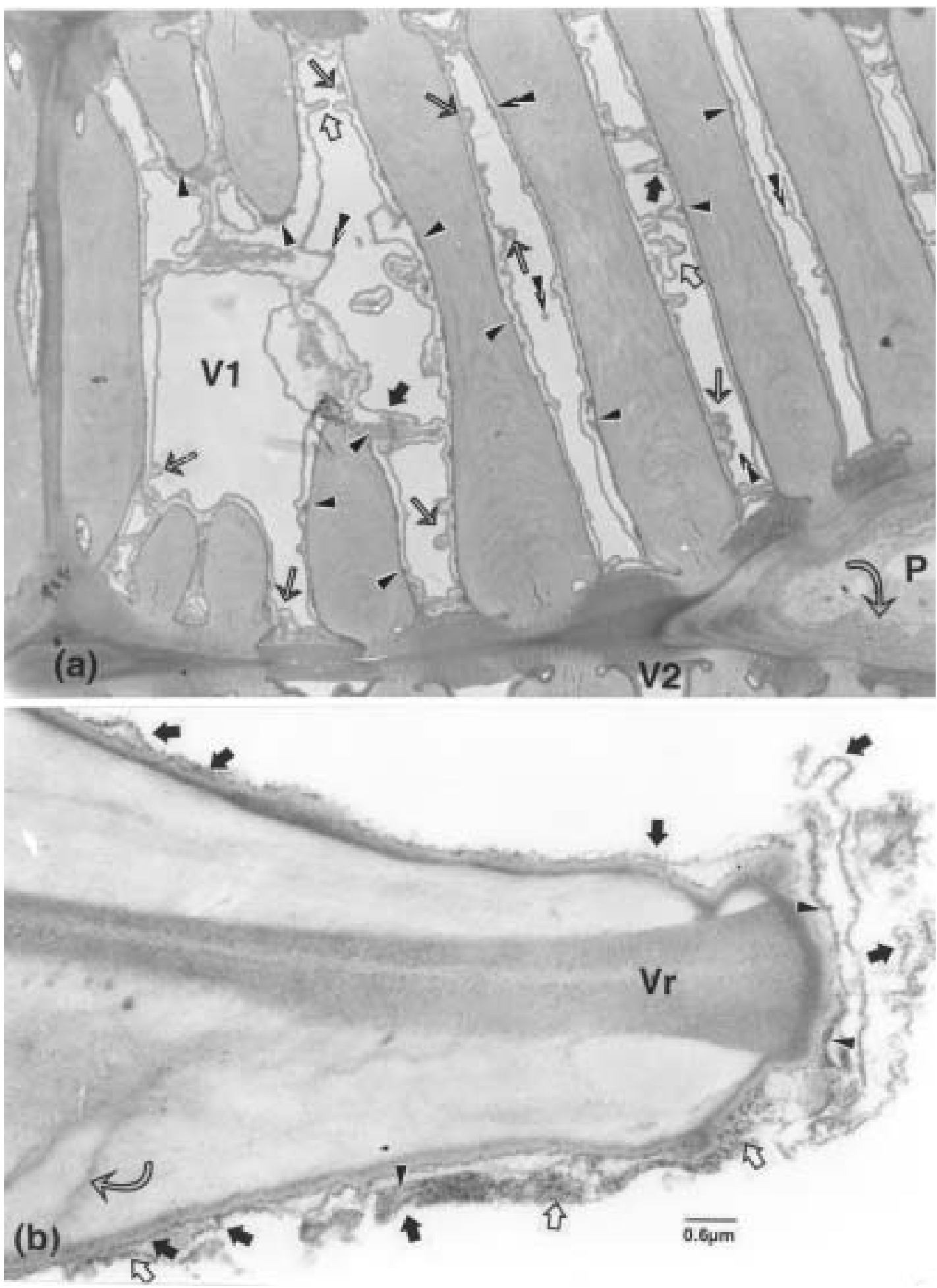

Figure 4. TEM observations. (a): vessel wall thickenings in V1 are covered with material of a lacy appearance formed by two diversely spaced opaque bands: one, apposed to the vessel wall, and associated at places with blobs of opaque matter (arrowheads), and the other extending into the lumen under various forms: small, circular (thin, light arrows) or compact (superimposed arrowheads), or as larger expansions (thick, light arrows). Junctions of bands may also yield other figures (dark arrows). Abundant material (curved arrow) occurs in the periplasm of the parenchyma cell bordered by V1 and the VWLM-containing V2. (b): small opaque particles are bound to opaque bands (dark arrows), seemingly paired at sites, lining a VWLM layer on each side of the vessel rim or meandering into the vessel lumen. Many similar particles, mixed with finer components (light arrows), are also associated with bands (arrowheads). Stretches of opaque matter (curved arrow) extend from the VWLM into the secondary wall. P, parenchyma cell; $\mathrm{V}$, vessel element; $\mathrm{Vr}$, vessel rim. 


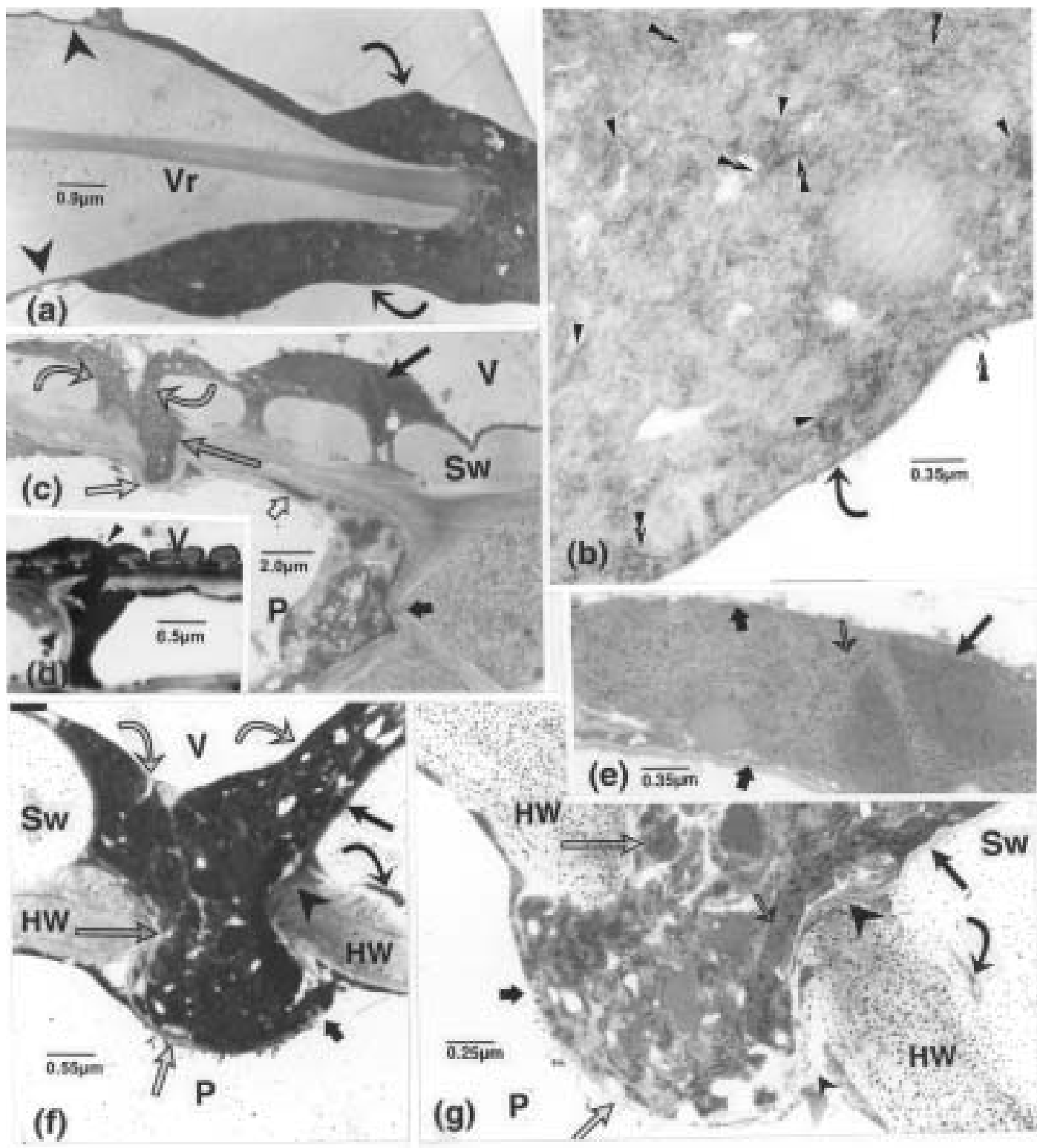

Figure 5. TEM observations, except $\mathbf{d}$. (a): the large masses of OM (opaque matter) (curved arrows) extending from the vessel lumen around the vessel rim thins out into a band (arrowheads), similar to the VWLM. (b): a similar mass (which also contoured a vessel rim) seen at a higher magnification, showing the presence of numerous small particles (arrowheads) included in fine matter or associated with fine strands (superimposed arrowheads). On the vessel lumen side, the mass is delimited by a fine band (curved arrow). (c): confluent masses of OM (curved arrows) covering the VWLM have at locations penetrated it and the pitted area (long, light arrow). The portion bulging into the paratracheal cell is covered by the cell inner wall layer (medium size, light arrow). Signs of plasma membrane and wall alterations are visible in one parenchyma cell (short, dark arrow). Similar OM is included in fine material (short, light arrow) in the cell periphery. The long, dark arrow points to a portion enlarged in e. (d): a large mass of OM (arrowhead) on vessel walls (corresponding to that in c) is connected through the pit and the parenchyma cell wall with similar matter in the cell. (e): numerous small particles (thin arrow) mixed with fine matter and compact bodies (long, dark arrow) containing still more opaque structures occur in the mass, along which a thin band is locally visible (short, dark arrows). (f): labelling for chitin. Convergent masses of OM (curved, light arrows) bulging from a pit chamber into a parenchyma cell (long, light arrow) are partially fenced herein by host wall material (short, light arrow). The OM in the parenchyma cell has permeated this thin layer (short, dark arrow) and is confluent with similar matter inside the cell. The VWLM (long, dark arrow) and similar matter seemingly extending from it into the vessel wall (curved, dark arrow) are well demarcated from the OM. The vessel secondary wall is labelled but not the ruptured pit membrane (arrowhead) and the parenchyma cell wall. (g): A section contiguous to that shown in f, printed at a shorter time exposure, with the same types of arrows pointing to similar areas. Labelling for cellulose. Gold particles are absent over the OM (long, light arrow), the VWLM, the ruptured pit membrane (large arrowhead). The Sw is less strongly labelled than the parenchyma cell wall. The distinct band (thin, light arrow) contains opaque bodies, similar to those shown in e. When comparing $\mathbf{f}$ and $\mathbf{g}$, the labelled band in $\mathbf{g}$ (small arrowhead) is apparently lacking in $\mathbf{f}$ (short, dark arrow), whereas the band indicated by the short, light arrow in $\mathbf{f}$ is not detectable in $\mathbf{g}$ (short, dark arrow). HW, parenchyma cell wall; $\mathrm{P}$, parenchyma cell; Sw, secondary wall thickening; $V$, vessel element; $\mathrm{Vr}$, vessel rim; VWLM, vessel wall lining material. 


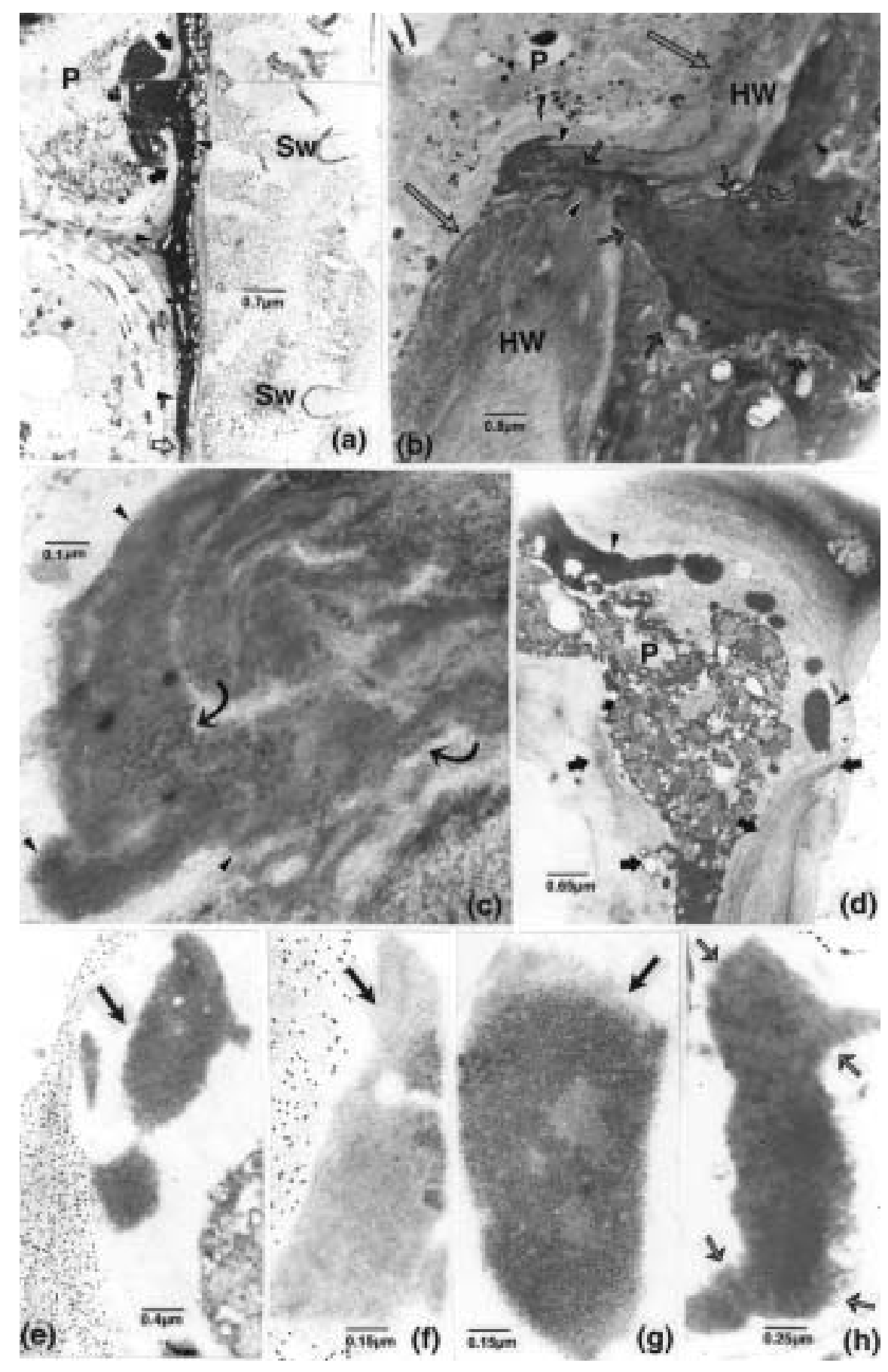

Figure 6. TEM observations. Alterations of cell wall and content are associated with OM (opaque matter). (a): labelling for cellulose. Portions of a long intercellular stretch of OM (arrowheads) bypassing intercellular areas and extending through the ruptured, incurved parenchyma cell wall (between dark arrows), next to a vessel element. The OM below terminates in a thin filament (light arrow) as was the case for the upper cropped-out portion. (b): OM, delimited by opaque bands (short arrows), thicker at sites in ex-folded parts (curved arrow) and bordered by altered host cell content, is hooking across the ruptured wall of the adjoining cell (arrowheads) and abutting on a band of matter (superimposed arrowheads) (viewed, in longer exposed prints, to be of a loose fibrillar nature). Opaque bodies border the altered native host cell wall (long arrows). (c): an enlarged portion of $\mathbf{b}$, in the area demarcated by the arrowheads. The matter displays arrays of filamentous structures (arrowheads) and compact opaque bodies (curved arrows). (d): presence of OM masses (arrowheads) in a matrix of fine matter in the periphery of a cell with altered content. Wall alterations and modifications of these cells are visible (arrows). (e-h): paramural OM masses (arrows), as in d, printed at higher magnifications and contrast. Labelling for cellulose, e and f, and for chitin, h. (e-g): the OM masses (arrows) display opaque particles and fine matter of a filamentous appearance. These particles are slightly larger ( $\mathbf{f}$ and $\mathbf{g}$ ) than the $15 \mathrm{~nm}$ gold particles (in $\mathbf{f}$ ). (h): this mass contains mostly crowded arrays of filamentous structures (arrows) and more compact but less well defined opaque bodies (compare with c). HW, parenchyma cell wall; P, parenchyma cell; Sw, vessel secondary wall or thickening. 


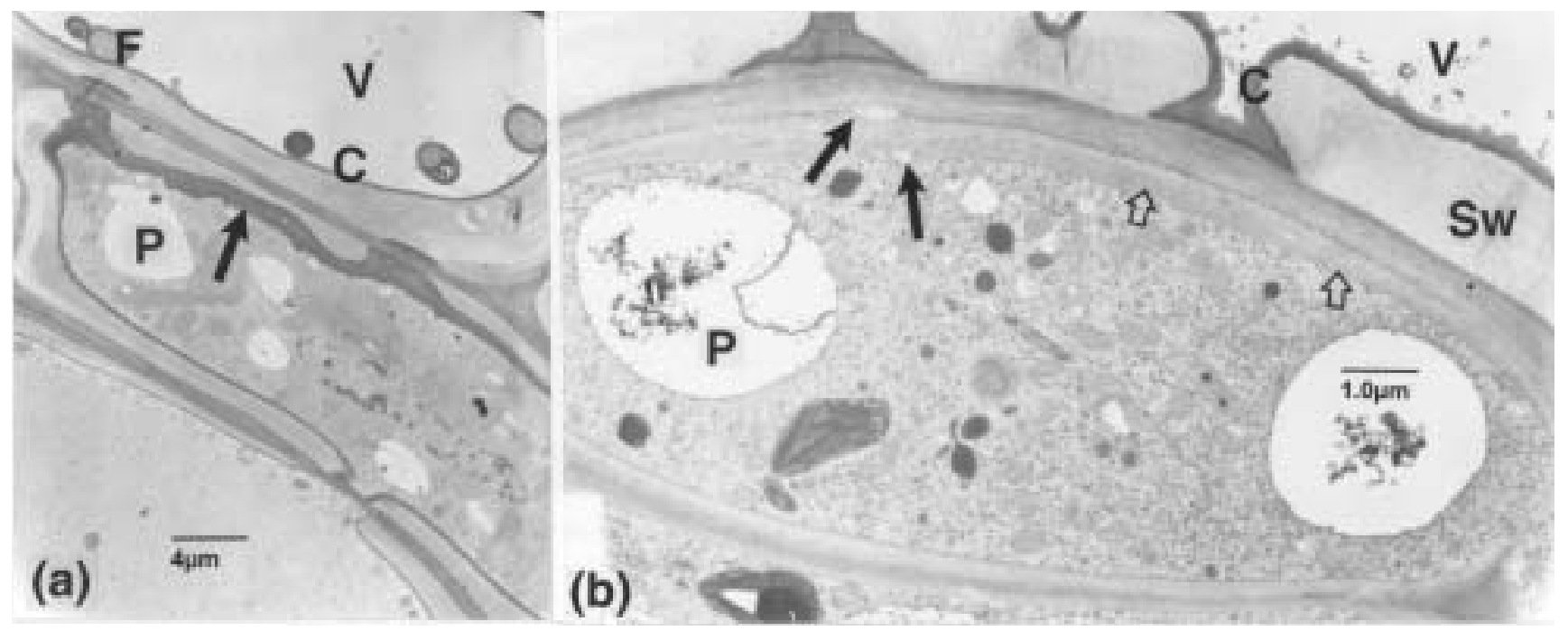

Figure 7. TEM observations. (a): in a parenchyma cell with secondary walls, next to a vessel element of the secondary xylem, an opaque, new inner wall layer (arrow) is thicker on the vessel side than on the opposite. (b): on the vessel side, a thickened parenchyma cell wall (light arrows), separated from the native wall by thin opaque bands, contains void areas (dark arrows). $C=$ VWLM; F, fungal cell; P, parenchyma cell; Sw, vessel secondary thickening, V, vessel element.

are considered to be analogous). Penetration of pit membranes and host cell wall layers by these masses was exemplified not only by continuity from the vessel lumen to within the cells, but also by discontinuities of the cell wall layer on both sides of the masses, as indicated by labelling for cellulose (Fig. $5 \mathrm{~g}$ ). In some cases, labelling of vessel secondary walls for cellulose (Fig. $5 \mathrm{~g}$ ) appeared to be lessened, but not for chitin (Fig. 5f). The masses and underlying VWLM were again free of labelling with both probes. Remnants of host organelles, plastids and mitochondria in particular, were not observed in the matter under consideration.

Opaque matter in host cell walls and periplasm. Masses of opaque matter similarly extended appreciable distances intercellularly and across cell walls (Fig. 6a) and, in some cells, directly across their altered content (Fig. 6b, c; these are from the same block used for LM observations). In these cases, the intruding matter was clearly delimited and structurally different from the altered cell content, and its extension circumscribed by deposition of new wall material (Fig. 6b). Matter of a similar appearance also occurred in the periplasm of affected cells (Fig. 6d-h) or extending across the cells (compare Fig. $6 \mathrm{~g}$ with Fig. $6 \mathrm{c}$ ). It was embedded in fine fribrillo-granular material which did not label for cellulose (Fig. 6f), compared with the native, altered or modified host wall (Fig. 6e, f), or it often displayed filamentous structures and opaque particles that were slightly larger than the $15 \mathrm{~nm}$ gold particles of the probes (Fig. 6f, g). Cells containing such opaque matter bordered or were proximate to invaded vessel elements.

Host cell reactions. Various reactions occurred in paratracheal cells and in those more remote from invaded vessel elements. Clear differences were observed between cells having secondary walls and those lacking these walls. A glimpse of the more usual reactions is presented here as a possible point of reference for introducing the many other more complex and outstanding reactions occurring at different stages of infection (to be presented in another publication). Thus, in cells having secondary walls (Figs. 3a, 7a), reactions were marked by the deposition of inner opaque or more lucent layers, which were generally thicker on the vessel side. In some of these cells, homogeneous matter was seemingly extruded from vacuolar bodies into periplasmic areas (Fig. 3a). Also, paratracheal cells without obvious secondary walls showed wall thickenings on the vessel side, when they were seemingly less altered (Fig. 7b). Lacunar areas frequently occurred in these depositions. Generally, cells showing this type of reaction displayed retraction of their content and the presence of vesicular or opaque bodies in the cell periplasm (Fig. 3e).

\section{DISCUSSION}

In this study of Verticillium-infected eggplants, particular attention was given to the vessel wall lining material (VWLM) and the occurrence of bands or masses of opaque matter in or crossing host walls or present in host cell periplasmic areas (this matter is referred to as $\mathrm{OM}$, as the case may be). The more unusual aspects of host cell reactions and of the morphology and ultrastructure of fungal elements will be presented in another publication.

The VWLM ranged from a thin opaque band to stratified layers of alternating similar and more lucent bands in which loop-like structures were regularly included. This material extended through pit 
membranes and vessel secondary walls, related to these wall alterations. Examples of links of this material with OM pervading middle lamellae and with that present in host cell periplasmic spaces have also been provided. These observations corroborate the majority of similar ones that we have made concerning other wilt diseases affecting tomato, carnation, and staghorn sumac (Ouellette et al. 2004b, 2004c, $2004 \mathrm{e}, 2005 \mathrm{~b})$. The matter deposited on vessel walls in plants infected with Verticillium and other fungal wilt pathogens has been defined as coating by other authors (Bishop and Cooper 1983, 1984; Gold et al. 1996; Pegg and Brady 2002; Pegg et al. 1976; Robb et al. 1979a, 1979b, 1987; Robb 2000). Some of the coating constituents may be structurally similar to those described herein, but other types mentioned by these authors may not be. Indeed, considering the arguments presented to support that this vessel wall lining material was solely of host origin and an expression of the same cause/effect relationships, in other words consistently of the same nature, many incongruities apparently exist that need to be examined more closely. Thus, mechanical injury, chemical treatments (Robb et al. 1980, 1991), inoculations with non-pathogens (Beckman 2000), bacterial and even viral infections were claimed (see citations in Robb et al. 1991) to produce the same effect and thus lead to accumulation of material of the same nature. Without expanding on all these various uncertainties, as will be examined in more detail in a forthcoming review paper, we wish to mention that if most of the material accumulating on vessel walls were of pathogen origin, as might be the case for similar bacterial infections (see Boher et al. 1996), then this material might contain many diverse compounds. Also, the compounds thought to be extrinsic to vessels should not be confused with those of normal occurrence. In some of the existing literature on the subject, it is at times perceivable that some of the material mentioned as coating may correspond to some normal host components (e.g. see Fig. 2b in Robb et al. 1991).

If comparisons were to be made between the various reports of material lining vessel walls and ours, one must consider first that the many types of coatings described by others (see Robb et al. 1979a) may correspond to different stages of the VWLM (or coating) formation. For example, the layer exposed to the vessel lumen may differently chemically react whether it corresponds to the opaque layer, present singly on the vessel wall or in the strata, than the more lucent exposed layer if it formed the innermost layer. Also, the occurrence of loops in the VWLM may correspond to some of the blisters mentioned in Robb et al. (see Fig. 13 in 1979a) but not those mentioned in Robb et al. (1991). Evidence has been obtained that most of these loops originated from some small fungal cells becoming encapsulated in the VWLM layers (results to be presented in another publication). Also, the apparent outgrowths, possibly cross-sectioned in some cases, from the membrane-like structures of the lacy network (see Fig. 4a), which are similar to structures of the alveolar network in infected elm trees and also shown to be confluent with the VWLM (Ouellette et al. 2004e), might match the structures also identified as blisters by Robb et al. (Figs. 14 and 17 in 1979a).
Another noteworthy feature is the occurrence of many opaque particles in large masses of matter covering vessel walls or ornamenting membranous-like structures. Particles present in similar matter present in vessel elements or in host walls associated with their alterations have been illustrated in Fusariuminfected susceptible carnation plants (Ouellette and Baayen 2000; Ouellette et al. 2004c) and in Dutch elm disease infected elms (see Fig. 7 in Ouellette et al. 2004e, and Figs. 34a and 35 in Ouellette and Rioux 1992) and observed to be closely connected to pathogen cells, for instance, as observed in elm and carnation (Ouellette et al. 2004c, 2004d). In some illustrations published by others, particles of the same size, texture and opacity can also be distinguished associated with the coating or pathogen cells of Verticillium dahliae (for example, see Figs. 14, 16, and 19 in Robb et al. 1977; Figs. 14 and 15 in Robb et al. 1979a; Figs. 4 and 5 in Robb et al. 1989).

The particles under consideration may also be compared, at least structurally, with those occurring in some of the masses of matter present in periplasmic spaces of altered parenchyma cells. In this case, one would be inclined to state that the particles are of ribosomal appearance. At low magnifications, these masses appeared opaque as were other masses viewed at higher magnifications but only containing fine structures such as those intermixed with the particles. The occurrence of similar OM and of its possible nature in elms and other hosts has been discussed in Ouellette et al. (2004d). In staghorn sumac, OM in host walls and that lining vessel walls was shown to label with a gold-complexed monoclonal antibody to DNA (Ouellette et al. 2004e, 2005b) with which such a probe would ordinarily not be expected to bind. A more detailed discussion on the subject is presented in Ouellette et al. (2005b). May it be stressed that the $\mathrm{OM}$ and related components under study do not appear to simply be degradation or excretion products, and that their occurrence in periplasmic spaces may not necessarily be an expression of host cell reactions (Shi et al. 1992). Indeed, again, the many long stretches of OM occurred in apparently intact middle lamellae bordering cells with still mostly normal host cell cytoplasm, or clearly different from its remnants when the cell content was completely altered. If all this OM were assigned a host origin, one would be confronted with odd situations, such as that shown in Fig. 6b, where welldelimited moribund cytoplasm extended sharply across other moribund cytoplasm and the cell wall, and was related in the adjoining cell to a pronounced reaction. Also, it would be difficult to explain how, in the same cells (see Fig. 6d-h), some portions of cytoplasm-like matter would be preserved whereas the remaining content would disintegrate. This does not exclude that in some cells, particularly in the secondary xylem, some components in periplasmic areas could originate from exocytosis. In the present case, however, these components could be well differentiated from the $\mathrm{OM}$ in question.

Our data do not preclude that various components, including phenolics (Robb 2000), enzymes such as hydrolases (Chamberland et al. 1991), amongst others, can occur in VWLM and the OM under 
consideration, but it must first be established whether they are the pioneers of VWLM occurrence. The main cumulative ultrastructural and cytochemical evidence for a pathogen origin of the components becoming apposed to vessel walls in this and the other wilt diseases considered (Ouellette et al. 2004b, 2004c, 2004e, and unpublished observations) may be summarized as follows: connections of the vessel wall lining matter with the pathogen elements; its relation with host wall penetration and alterations; labelling, in carnation, for chitin and in staghorn sumac for DNA; and connections with similar opaque matter present in host walls and in cell periplasmic areas. Undoubtedly, the use of other specific probes at the TEM level would help to unravel other features of this matter and confirm its nature and role in disease development, particularly if it represents a cause rather than an effect. In many cases, a lack of a relation between the VWLM (coating) and conditions of susceptibility or resistance was reported (Pegg and Brady 2002). To account for discrepancies that did not exactly conform to a coating/defence scheme in Verticillium-infected tomatoes, some workers (Gold and Robb 1995; Gold et al. 1996) have proposed the following possibilities: delayed formation of coating and/or its suppression. Alternatively, the fact that the extraneous material occurring on vessel walls may primarily not be of host origin would eliminate the need for these types of considerations. However, any other valid observation concerning that material in vessel lumina could still be incorporated, although interpreted differently, into a "host origin" postulate. For instance, the stereoscopic images (Fig. 5c, d in Bishop and Cooper 1983) of opaque matter and radiating filamentous-like structures crossing vessel walls and clearly connected to similar coating material show analogies with many of the situations that we have observed, in elm in particular (Ouellette 1978b; Ouellette et al. 2004d, and citations therein).

A feature to be underlined is that pit membranes remained relatively distinct even when they were strongly dislocated, a situation which was, however, less severe for intertracheary membranes. These were characterized by three demarcated layers: a shredded one, unlabelled for cellulose, a more compact and opaque cellulose-labelled layer, and the unlabelled VWLM layer. This type of alteration mirrored that of pit membranes of half-bordered pits in the metaxylem in DED affected elms and Fusariuminfected carnations (Ouellette 1978a, 1978b; Ouellette et al. 1999, 2004b, 2004c; Ouellette and Rioux 1993) and often of intertracheary pit membranes in staghorn sumac (Ouellette et al. 2005a). In all instances, the term "swelling of pit membranes" should not apply, in our opinion, when it is primarily attributed to covering layers of extraneous matter, likely of a pathogen origin in most cases. This situation was observed to be general for intertracheary pit membranes in the diseases studied (Ouellette et al. 2004d), except in staghorn sumac, as mentioned above.
In considering these types of alterations and labelling, no indications were obtained that breakdown products from pit membranes were released into vessel lumina, unless the VWLM layer, also labelled, was ruptured. The still labelled outer pit membrane region indicates that breakdown products or adsorption of other components did not interfere with the reaction, as was the case for the walls of altered and reacting cells showing increased opacities. Hence, if the opaque vessel occluding components or VWLM corresponded to breakdown products of pit membranes, they would still label for cellulose, a fact that was observed only once in infected staghorn sumac (Ouellette et al. 2005a). Otherwise, the cellulose-labelled substrate in vessel lumina had a more lucent appearance, which in the present case was traceable to detached or broken portions of secondary wall thickenings. As some evidence was obtained that the subtending host wall was much degraded, the detachment of vessel wall components cannot be due to simple mechanical damage resulting from sample manipulation. In comparison, pectinlabelled compounds present in vessel lumina in the wilt-affected plants studied were more often than otherwise found to be released from tyloses or directly secreted by paratracheal cells (Et-Touil et al. 2005; Ouellette et al. 1999, 2004d; Rioux et al. 1998). Therefore, gel formation, if any in the present case, would not originate from host wall alteration as mentioned by others (Beckman 1987; Cooper 1998; Vander Molen et al. 1977, for example).

The few types of host cell reactions described here, e.g. deposition of appositions and new wall material, following or not a retraction of the cell content, were similar to those noted in other systems. Whereas those occurring in the secondary xylem, as briefly described here, might coincide with a defensive response hindering further tissue invasion by the pathogen, those in the metaxylem might not be. Indeed, in samples considered to be of older infection stages, most of the paratracheal and some neighbouring cells were severely altered.

\section{ACKNOWLEDGEMENTS}

This work was initiated by the late Dr. Gilles Pelletier from the Faculté des sciences de I'agriculture et de I'alimentation, Université Laval, Québec, and we publish this work in his honour. We are thankful to colleagues at the Laurentian Forestry Centre (LFC): Dr. Michel Cusson and Ms. Marie Simard for their comments and suggestions during the preparation of the manuscript, Ms. Pamela Cheers and Ms. Isabelle Lamarre for their technical editing work, and Ms. Diane Paquet for her photo work. This study was approved and supported by the late Dr. Marcel Lortie when he was the Director General of the LFC. We are also grateful to the present management of the LFC who have enabled us to finalize this work. 


\section{REFERENCES}

Beckman, C.H. 1987. The nature of wilt diseases. APS Press, The American Phytopathological Society, St. Paul, MN, USA. $175 \mathrm{pp}$.

Beckman, C.H. 2000. Phenolic-storing cells: keys to programmed cell death and periderm formation in wilt disease resistance and in general defence responses in plants. Physiol. Mol. Plant Pathol. 57 : 101-110.

Bishop, C.D., and R.M. Cooper. 1983. An ultrastructural study of vascular colonization in three vascular wilt diseases. I. Colonization of susceptible cultivars. Physiol. Plant Pathol. $23:$ 323-343.

Bishop, C.D., and R.M. Cooper. 1984. Ultrastructure of vascular colonization by fungal wilt pathogens. II. Invasion of resistant cultivars. Physiol. Plant Pathol. 24 : 277-289.

Boher, B., I. Brown, M. Nicole, K. Kpemoua, V. Verdier, U. Bonas, J.F. Daniel, J.P. Geiger, and J. Mansfield. 1996. Histology and cytochemistry of interactions between plants and Xanthomonads. Pages 193-210 in M. Nicole and V. Gianinazzi-Pearson (eds.), Histology, ultrastructure and molecular cytology of plant-microorganism interactions. Kluwer Academic Publishers, Dordrecht, The Netherlands.

Chamberland, H., G.B. Ouellette, F.J. Pauzé, and P.M Charest. 1991. Immunocytochemical localization of tomato pectinesterase in root cells of tomato plants infected by Fusarium oxysporum f.sp. radicis-lycopersici. Can. J. Bot. 69 : 1265-1274.

Charest, P.M., G.B. Ouellette, P. Blais, and H. Chamberland. 2004. Irregular growth forms and cell wall modifications, polygalacturonase detection, and endocell formation in Fusarium oxysporum f.sp. radicis-lycopersici infecting tomato plants, as studied ultrastructurally and cytochemically. Mycol. Prog. 3 : 137-150.

Cirulli, M., M. Amenduni, and C. Colella. 1998. Resistance to verticillium wilt in eggplant. Pages 173-177 in E.C. Tjamos, R.C. Rowe, J.B. Heale, and D.R. Fravel (eds.), Advances in Verticillium research and disease management. APS Press, The American Phytopathological Society, St. Paul, MN, USA.

Cooper, R.M. 1998. Verticillium-host interactions: past achievements and future molecular prospects. Pages 144-150 in E.C. Tjamos, R.C. Rowe, J.B. Heale, and D.R. Fravel (eds.), Advances in Verticillium research and disease management. APS Press, The American Phytopathological Society, St. Paul, MN, USA.

Cooper, R.M., M.L.V. Resende, J. Flood, and R. Mepsted. 1998. Physiology and biochemistry of compatible and incompatible responses of Theobroma cacao to Verticillium dahliae. Pages 160-165 in E.C. Tjamos, R.C. Rowe, J.B. Heale, and D.R. Fravel (eds.), Advances in Verticillium research and disease management. APS Press, The American Phytopathological Society, St. Paul, MN, USA.

Et-Touil, A., D. Rioux, F.M. Mathieu, and L. Bernier. 2005 External symptoms and histopathological changes following inoculation of elms putatively resistant to Dutch elm disease with genetically close strains of Ophiostoma. Can. J. Bot. $83: 656-667$.

Garibaldi, A., A. Minuto, and M.L. Gullino. 2005. Verticillium wilt incited by Verticillium dahliae in eggplant grafted on Solanum torvum in Italy. Plant Dis. 89 : 777.

Gold, J., and J. Robb. 1995. The role of the coating response in Craigella tomatoes infected with Verticillium dahliae, races 1 and 2. Physiol. Mol. Plant Pathol. 47 : 141-157.

Gold, J., B. Lee, and J. Robb. 1996. Colonization of tomatoes by Verticillium dahliae: determinative phase II. Can. J. Bot. 74 : 1279-1288.
McFadden, H. 1998. Prospects for controlling vascular wilt diseases of cotton and other crops by genetic engineering. Pages 166-171 in E.C. Tjamos, R.C. Rowe, J.B. Heale, and D.R. Fravel (eds.), Advances in Verticillium research and disease management. APS Press, The American Phytopathological Society, St. Paul, MN, USA.

Ouellette, G.B. 1978a. Fine structural observations on substances attributable to Ceratocystis ulmi in American elm and aspects of host cell disturbances. Can. J. Bot. 56 : 2550-2566.

Ouellette, G.B. 1978b. Light and electron microscope studies on cell wall breakdown in American elm xylem tissues infected with Dutch elm disease. Can. J. Bot. 56 : 26662693.

Ouellette, G.B., and R.P. Baayen. 2000. Peculiar structures occurring in vessel walls of the susceptible carnation cultivar Early Sam infected with Fusarium oxysporum f. sp. dianthi. Can. J. Bot. $78: 270-277$.

Ouellette, G.B., and H. Chamberland. 1993. Comparative ultrastructural observations of host wall alterations in elm and eggplant infected respectively by Ophiostoma ulmi and Verticillium dahliae. 6th Int. Congr. Plant Pathol. Montreal, Quebec, Canada. Abstr. p. 236.

Ouellette, G.B., and D. Rioux. 1992. Anatomical and physiological aspects of resistance to Dutch elm disease. Pages 257-307 in R.A. Blanchette and A.R. Biggs (eds.), Defense mechanisms of woody plants against fungi. SpringlerVerlag, Berlin, Germany.

Ouellette, G.B., and D. Rioux. 1993. Alterations of vessel elements and reactions of surrounding tissues in the DED syndrome. Pages 255-292 in M.B. Sticklen and J.L. Sherald (eds.), Dutch elm disease research: cellular and molecular approaches. Springer-Verlag, New York.

Ouellette, G.B., N. Méthot, H. Chamberland, C. Côté, and J.-G. Lafontaine. 1995. Cytology of irregular growth forms of Ophiostoma ulmi and Ophiostoma novo-ulmi growing through millipore filter membranes and sterilized elm wood sections. Can. J. Microbiol. 41: 1095-1110.

Ouellette, G.B., R.P. Baayen, M. Simard, and D. Rioux. 1999. Ultrastructural and cytochemical study of colonization of xylem vessel elements of susceptible and resistant Dianthus caryophyllus by Fusarium oxysporum f. sp. dianthi. Can. J. Bot. 77 : 644-663.

Ouellette, G.B., R.P. Baayen, H. Chamberland, M. Simard, D. Rioux, and P.M. Charest. 2004a. Cytochemical labeling for fungal and host components in plant tissues inoculated with fungal wilt pathogens. Microsc. Microanal. 10 : 449-461.

Ouellette, G.B., R.P. Baayen, D. Rioux, and M. Simard. 2004b. Peculiar ultrastructural characteristics of fungal cells and of other elements apposed to and in vessel walls in plants of a susceptible carnation cultivar, infected with Fusarium oxysporum f.sp. dianthi race 2. Phytoprotection 85: 121-138.

Ouellette, G.B., D. Rioux, M. Simard, and R.P. Baayen. 2004c. Occurrence of paracrystalloids and their particles in resistant and susceptible carnation plants infected with Fusarium oxysporum f.sp. dianthi race 2. Phytoprotection $85: 139-151$.

Ouellette, G.B., D. Rioux, M. Simard, and M. Cherif. 2004d. Ultrastructural and cytochemical studies of host and pathogens in some fungal wilt diseases: retro- and introspection towards a better understanding of DED. In L. Gil, A. Solla, and G.B. Ouellette (eds.), New approaches to elm conservation. Investig. Agrar.: Sist. Recur. For. 13 : $119-145$.

Ouellette, G.B., D. Rioux, M. Simard, H. Chamberland, M. Cherif, and R.P. Baayen. 2004e. Ultrastructure of the alveolar network and its relation to coating on vessel walls in elms infected by Ophiostoma novo-ulmi and in other plants affected by similar wilt diseases. In L. Gil, A. Solla, and G.B. Ouellette (eds.), New approaches to elm conservation. Investig. Agrar.: Sist. Recur. For. 13 : 147-160. 
Ouellette, G.B., M. Cherif, M. Simard, and L. Bernier. 2005a. Histopathology of Fusarium wilt of staghorn sumac (Rhus typhina) caused by Fusarium oxysporum f. sp. callistephi race 3 . I. Modes of host tissue invasion. Phytoprotection 86 : 157-174.

Ouellette, G.B., D. Rioux, and M. Simard. 2005b. Histopathology of Fusarium wilt of staghorn sumac (Rhus typhina) caused by Fusarium oxysporum f. sp. callistephi race 3. II. Characteristics of the abundant opaque matter occurring in host walls and cells associated with their alterations. Phytoprotection 86 : 175-187.

Pegg, G.F., and B.L. Brady. 2002. Verticillium wilts. CABI Publishing. Oxon, UK. 541 pp.

Pegg, G.F., K. Gull, and R.J. Newsam. 1976. Transmission electron microscopy of Verticillium albo-atrum in xylem vessels of tomato plants. Physiol. Plant Pathol. 8 : 221 . 224.

Rioux, D., M. Nicole, M. Simard, and G.B. Ouellette. 1998. Immunocytochemical evidence that secretion of pectin occurs during gel (gum) and tylosis formation in trees. Phytopathology 88 : 494-505.

Robb, J. 2000. Verticillium. Pages 788-795 in J. Lederberg (ed.), Encyclopedia of Microbiology, 2nd ed., Vol. 4 (Q-Z).

Robb, J., L. Busch, J.D. Brisson, and B.C. Lu. 1977 Ultrastructure of wilt syndrome caused by Verticillium dahliae. III. Chronological symptom development in sunflower leaves. Can. J. Bot. 55 : 139-152.

Robb, J., A. Smith, J.D. Brisson, and L. Busch. 1979a. Ultrastructure of wilt syndrome caused by Verticillium dahliae. VI. Interpretive problems in the study of vessel coatings and tyloses. Can. J. Bot. 57 : 795-821.

Robb, J., J.D. Brisson, L. Busch, and B.C. Lu. 1979b. Ultrastructure of wilt syndrome caused by Verticillium dahliae. VII. Correlated light microscope and transmission electron microscope identification of vessel coatings and tyloses. Can. J. Bot. $57: 822-834$.
Robb, J., L. Busch, and W.E. Rauser. 1980. Zinc toxicity and xylem vessel wall alterations in white beans. Ann. Bot. 46 : 43-50.

Robb, J., D.A. Powell, and P.F.S. Street. 1987. Time course of wall-coating secretion in Verticillium-infected tomatoes. Physiol. Mol. Plant Pathol. 31 : 217-226.

Robb, J., D.A. Powell, and P.F.S. Street. 1989. Vascular coating: a barrier to colonization by the pathogen in Verticillium wilt of tomato. Can. J. Bot. 67 : 600-607.

Robb, J., S.-W. Lee, R. Mohan, and P.E. Kolattukudy. 1991. Chemical characterization of stress-induced vascular coating in tomato. Plant Physiol. 97 : 528-536.

Shi, J., W.C. Mueller, and C.H. Beckman. 1992. Vessel occlusion and secretory activities of vessel contact cells in resistant or susceptible cotton plants infected with Fusarium oxysporum f.sp. vasinfectum. Physiol. Mol. Plant Pathol. 40 : 133-147.

Tjamos, E.C., R.C. Rowe, J.B. Heale, and D.R. Fravel (eds.). 1998. Advances in Verticillium research and disease management. APS Press, The American Phytopathological Society, St. Paul, MN, USA

Tomescu, A., V. Voican, and V. Răcaru. 1998. Some physiological changes induced by the fungus Verticillium dahliae in pepper plants. Pages 151-154 in E.C. Tjamos, R.C. Rowe, J.B. Heale, and D.R. Fravel (eds.), Advances in Verticillium research and disease management. APS Press, The American Phytopathological Society, St. Paul, MN, USA.

Vander Molen, G.E., C.H. Beckman, and E. Rodehorst. 1977. Vascular gelation: a general response phenomenon following infection. Physiol. Plant Pathol. 11 : 95-100. 